Article

\title{
Potential of Biogas Production from Processing Residues to Reduce Environmental Impacts from Cassava Starch and Crisp Production-A Case Study from Malaysia
}

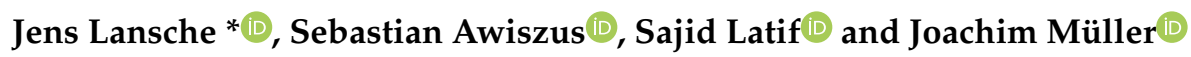 \\ Institute of Agricultural Engineering, Tropics and Subtropics Group, University of Hohenheim, 70599 Stuttgart, \\ Germany; sebastian.awiszus@uni-hohenheim.de (S.A.); s.latif@uni-hohenheim.de (S.L.); \\ joachim.mueller@uni-hohenheim.de (J.M.) \\ * Correspondence: info440e@uni-hohenheim.de or jlansche@uni-hohenheim.de; Tel.: +49-711-459-23464
}

Received: 8 March 2020; Accepted: 22 April 2020; Published: 24 April 2020

check for updates

\begin{abstract}
The cultivation of cassava (Manihot esculenta) is widely spread in a variety of tropical countries with an estimated annual production of 291.9 million tons. The crop is the most important source of carbohydrates in producing countries. In Malaysia, cassava is mainly cultivated for starch production. Despite the economic and nutritional importance of cassava, there is only limited knowledge available regarding the overall environmental impacts of cassava starch production or the production of alternative food products like cassava crisps. This study presents an environmental assessment of different scenarios of cassava production and processing by a life cycle assessment (LCA) approach. The results indicate that the environmental impacts of cassava-based products can be reduced considerably with the utilization of processing residues for anaerobic digestion if the resulting biogas is used for the production of electricity and heat. In the industrial scenario, the results indicate that the highest relative reductions are achieved for cumulated energy demand (CED), global warming potential (GWP) and deforestation (DEF) with $-39 \%,-26 \%$ and $-18 \%$, respectively, while in the advanced scenario, environmental impacts for CED, GWP, ozone formation potential (OFP) and water stress index (WSI) can be reduced by more than $10 \%$ with $-281 \%,-37 \%,-16 \%$ and $-14 \%$, respectively. The impacts for global warming potential found in this study are slightly higher compared to other studies that focused on the carbon footprint of starch production from cassava, while the savings due to biogas production are similar.
\end{abstract}

Keywords: LCA; life cycle assessment; cassava crisps; anaerobic digestion; renewable energy; circular economy

\section{Introduction}

The cultivation of cassava (Manihot esculenta) is widely spread in a variety of tropical countries with an estimated annual production of 291.9 million tons [1]. Cassava products are used for human nutrition, animal feed as well as for industrial applications and energy supply [2]. Both the roots and leaves of cassava can be used as food. The crop is the most important source of carbohydrates in producing countries and it can contribute to the supply of proteins, micronutrients and minerals additionally [3]. The latter nutrients are mainly provided by cassava leaves, if consumed. As reported by Vetter [4], both cassava roots and leaves contain cyanogenic components that vary in concentration according to genetic variety and growth stage and need to be detoxified before utilization in animal or human nutrition. 
Due to the diversity of ingredients and its suitability for different applications, cassava is a valuable feedstock for cascade use. An example for the implementation of cascade use is the concept of the green biorefinery [5]. In comparison with conventional production systems, processing in green biorefineries can lead to environmental advantages. However, the dissemination of such concepts in developing countries is still very limited. A simple implementation of cascade use is a utilization of residues for energy production and plant nutrition. While recent studies assessed the potential of several substrates for biogas production in Malaysia [6,7], there is only little knowledge available about the utilization of residues from cassava processing and its environmental consequences. In Malaysia, cassava is mainly cultivated for starch production [8]. Different technologies exist for processing of cassava roots to cassava starch [9]. In addition, alternative food products can be produced that are rich in carbohydrates, like cassava crisps, which are deep-fried cassava slices.

Torquati et al. have shown that there can be trade-offs between economic and ecological benefits in agricultural production systems [10]. However, despite the economic and nutritional importance of cassava, there is only limited knowledge available regarding the overall environmental impacts of cassava starch production or the production of alternative food products like cassava crisps. In several studies, the carbon footprint was evaluated, while full life cycle assessment (LCA) studies for cassava starch production are not available yet to our knowledge, especially not for Malaysia. For Thailand, Usubharatana and Phungrassami [11] found that producing $1 \mathrm{t}$ of cassava starch causes about $600 \mathrm{~kg}$ of $\mathrm{CO}_{2}$-equivalents $\left(\mathrm{CO}_{2}\right.$-eq) where the agricultural production dominated the impact (40-59\%). Hansupalak et al. [12] reported higher emissions with 609-966 kg CO 2 -eq. For starch production in Thailand, Vietnam, Colombia, Tran et al. [9] reported $93-539 \mathrm{~kg} \mathrm{CO}$-eq without taking into consideration the production of cassava roots. Olaniran et al. assessed the environmental impacts of processing cassava roots to flour [13] and reported $11 \mathrm{~kg} \mathrm{CO}$ eq per $\mathrm{kg}$ of flour. For the production of cassava crisps, however, there is no information available yet. The lack of knowledge about the environmental impacts of cassava products becomes relevant in the context of the international goals for sustainable development [14]. Sala and Castellani propose a method based on life cycle assessment (LCA) as an indicator and basis for monitoring the sustainable development goal No. 12 "sustainable production and consumption" [15].

This study presents an environmental assessment of different scenarios of cassava production and processing by a life cycle assessment (LCA) approach. In addition to estimating the absolute level of environmental impacts, the question is answered to what extent the production of biogas from residual materials can contribute to a reduction in the environmental impacts of cassava starch production. As previous studies indicate a major influence of primary agricultural production on the greenhouse gas emissions of cassava starch production, it is also hypothesized that other environmental impacts are significantly influenced by this production step. Therefore, a specific focus is set on primary production.

\section{Materials and Methods}

\subsection{Description of the System under Study}

\subsubsection{Feedstock for the Production of Starch, Crisps and Biogas}

Cassava is considered the main feedstock. Cassava cultivation covers all steps starting from the production of seedlings, including essential disinfection, field preparation, planting, fertilization and pest control as well as harvesting. The processing of the main parts of the cassava plant (roots, stems and peel) is included in the scenarios. For the evaluation of different cultivation intensities besides the traditional cultivation based on manual labor, a modern, i.e., fully mechanized scenario, was also modelled. Table 1 shows the assumptions for the traditional system and the modern system. Both systems were modelled with two sub-scenarios where leaves are (i) left on the field and burned or (ii) harvested. For the combustion of leaves, the following emissions were taken into consideration: $\mathrm{CO}_{2}, \mathrm{SO}_{2}$, dust (PM10 and PM2.5) as well as $\mathrm{NO}_{x}$. 
Table 1. Main characteristics of traditional and modern cassava production system under study.

\begin{tabular}{ccc}
\hline Parameter & Traditional & Modern \\
\hline Plowing (number of crossings) & manual (1) & mechanized (1) \\
Harrowing (number of crossings) & - & mechanized (2) \\
Mulching (number of crossings) & manual (1) & mechanized (3) \\
Planting, pcs/ha & 26,000 & 26,000 \\
Harvesting & manual & mechanized \\
Loading of crops & manual & mechanized \\
Fertilizing & manual & mechanized \\
Cattle manure, kg/ha & - & $15^{\prime} 000$ \\
Manure application & - & mechanized \\
NPK (15/15/15), kg/ha & 350 & 350 \\
Cutting stems and leaves & manual & mechanized \\
Tuber yield, $\mathrm{t} / \mathrm{ha}$ & 5.0 & 17.8 \\
Leaves yield, $\mathrm{t} / \mathrm{ha}$ & 0.6 & 2.04 \\
\hline
\end{tabular}

\subsubsection{Processing of Roots}

The main characteristics and assumptions of the different processing steps are given in Table 2.

Table 2. Main characteristics and assumptions for cassava starch extraction (based on [16]).

\begin{tabular}{|c|c|c|}
\hline Parameter & Unit & Value \\
\hline \multicolumn{3}{|l|}{ Cassava peeling } \\
\hline Peel, percentage of fresh roots & $\%$ & 10 \\
\hline Wastewater per ton of fresh roots & $\mathrm{m}^{3} / \mathrm{t}$ & 1.3 \\
\hline Energy demand per ton of fresh roots & $\mathrm{MJ} / \mathrm{t}$ & 1.7 \\
\hline \multicolumn{3}{|l|}{ Cassava chopping } \\
\hline Energy demand per ton of peeled roots & $\mathrm{MJ} / \mathrm{t}$ & 16.67 \\
\hline Water demand per ton of peeled roots & $\mathrm{m}^{3} / \mathrm{t}$ & 0.3 \\
\hline \multicolumn{3}{|l|}{ Fiber and pulp separation } \\
\hline Water demand per ton of chopped roots & $\mathrm{m}^{3} / \mathrm{t}$ & 1.4 \\
\hline Sulphur demand per ton of chopped roots & $\mathrm{kg} / \mathrm{t}$ & 0.13 \\
\hline Waste fibers, wet per ton of chopped roots & $\mathrm{t} / \mathrm{t}$ & 1.01 \\
\hline Starch extract, wet per ton of chopped roots & $t / t$ & 0.89 \\
\hline \multicolumn{3}{|l|}{ Starch separation and dewatering } \\
\hline Water demand per ton of starch extract & $\mathrm{m}^{3} / \mathrm{t}$ & 0.5 \\
\hline Electricity for dewatering per ton of starch extract & $\mathrm{MJ} / \mathrm{t}$ & 12.5 \\
\hline Electricity, separation per ton of starch extract & $\mathrm{MJ} / \mathrm{t}$ & 18 \\
\hline Starch loss per ton of starch extract & $\mathrm{kg} / \mathrm{t}$ & 2.3 \\
\hline Starch per ton of starch extract & $\mathrm{t} / \mathrm{t}$ & 0.18 \\
\hline \multicolumn{3}{|l|}{ Starch drying } \\
\hline Thermal energy demand per ton of wet starch & $\mathrm{MJ} / \mathrm{t}$ & 1.0 \\
\hline Starch loss per ton of dry starch & $\mathrm{kg} / \mathrm{t}$ & 5.0 \\
\hline $\begin{array}{l}\text { Wastewater disposal (all processing steps) } \\
\text { Wastewater per ton of fresh roots }\end{array}$ & $\mathrm{m}^{3} / \mathrm{t}$ & 4.5 \\
\hline BOD per $\mathrm{m}^{3}$ waste water & $\mathrm{g} / \mathrm{m}^{3}$ & 1410 \\
\hline Cyanide per $\mathrm{m}^{3}$ waste water & $\mathrm{g} / \mathrm{m}^{3}$ & 0.17 \\
\hline Nitrate per $\mathrm{m}^{3}$ waste water & $\mathrm{g} / \mathrm{m}^{3}$ & 470 \\
\hline
\end{tabular}

It was assumed that peeling is done with a commercially available abrasive peeling machine. For the production of dried native starch, the following production steps were assumed: (i) root washing, (ii) chopping and grinding, (iii) the separation of fibrous residues, (iv) dewatering and protein separation, (v) dehydration, (vi) drying, and (vii) packaging. 
For producing cassava crisps, it was assumed that the harvested roots are peeled like in the starch production scenario. After peeling, the roots are sliced with an electric slicer with an energy demand of $4.6 \mathrm{kWh}$ per ton of cassava roots. During slicing, $10 \%$ losses are considered. After slicing, the raw cassava chips are deep-fried using energy from LPG (70\% Propane/30\% Butane). The frying pan was considered to be equipped with a $1.2 \mathrm{~kW}$ burner, $80 \%$ occupancy and a cassava throughput of $100 \mathrm{~kg} / \mathrm{h}$. Frying oil consumption was estimated at $0.25 \mathrm{t}$ per ton of raw cassava chips and mass ratio of fried crisps to raw chips at 1:2, based on data provided by Mouron et al. [17] and Vitrac et al. [18]. For frying, the use of palm oil is assumed, which would be reused three times before replacement.

\subsubsection{Cassava Leaves}

For the handling of the cassava leaves, two scenarios were modelled. In scenario 1, leaves remain on the field and are burnt with emissions of particulate matter, $\mathrm{SO}_{2}$ and $\mathrm{NO}_{\mathrm{x}}$, calculated according to [19]. As a potential alternative, leaves could also serve as biogas substrate. If the leaves are removed from the field, the amount of required fertilizer increases accordingly.

\subsubsection{Biogas Production and Utilization}

Residues from cassava production and processing (i.e., leaves, peels and pulp) as well as from frying cassava crisps (i.e., waste palm oil) can be converted to biogas in anaerobic digestion plants. Substrate specific biogas production potential was determined in previous studies using the so-called "Hohenheimer Biogasertragstest (HBT)" (Universität Hohenheim-Landesanstalt für Agrartechnik und Bioenergie, Stuttgart, Germany), which is based on standard VDI 4630 [20]. The results showed a methane production potential of 0.239 and $0.292 \mathrm{~m}^{3}$ per kg of volatile solids (VS) for cassava leaves and cassava pulp, respectively [21,22]. To ensure the sufficient trace element supply of the biogas process, animal manure was added with a share of $25 \%$ on the substrate mixture. Produced biogas is assumed to be burned in a combined heat and power plant (CHP) to substitute conventional electricity (Malaysian grid mix) and heat (natural gas). Biogas digestate is assumed to be used as organic fertilizer and thus substitutes NPK fertilizer.

\subsection{Life Cycle Inventory (LCI)}

\subsubsection{Goal, Scope and Functional Unit}

The aim of this study is the assessment of different utilization pathways for cassava biomass in starch production from an environmental perspective. As the main purpose of cassava products is to supply carbohydrates in the form of starch, the functional unit (FU) is defined as $1 \mathrm{~kg}$ of cassava starch, either in the form of dried native starch or based on the corresponding starch content in cassava crisps. In addition to the absolute level of environmental impacts, the contribution of biogas production from residues to reducing environmental impacts is also assessed.

\subsubsection{System Boundaries}

The system was modelled from cradle to factory gate, as shown in Figure 1. The inputs of organic and mineral fertilizers, plant protection products, agricultural machinery, as well as seedlings and the input of energy carriers are considered. Different scenarios are modelled as described in Table 1. Cassava cultivation and processing is modelled based on data from a case study in Malaysia and is supplemented by data from literature to close existing data gaps. The processing of cassava includes different pathways with native cassava starch and cassava crisps as products. Stems are assumed to be used for the provision of seedlings. Residues from starch extraction and crisp production are rich in highly degraded fiber material and can be used in an anaerobic digestion plant for further degradation. Cattle manure is added to the substrate as inoculum and to increase process stability and gas yield. The utilization of digestate as organic fertilizer in cassava cultivation is considered with the corresponding content of nitrogen, phosphorus and potassium. 


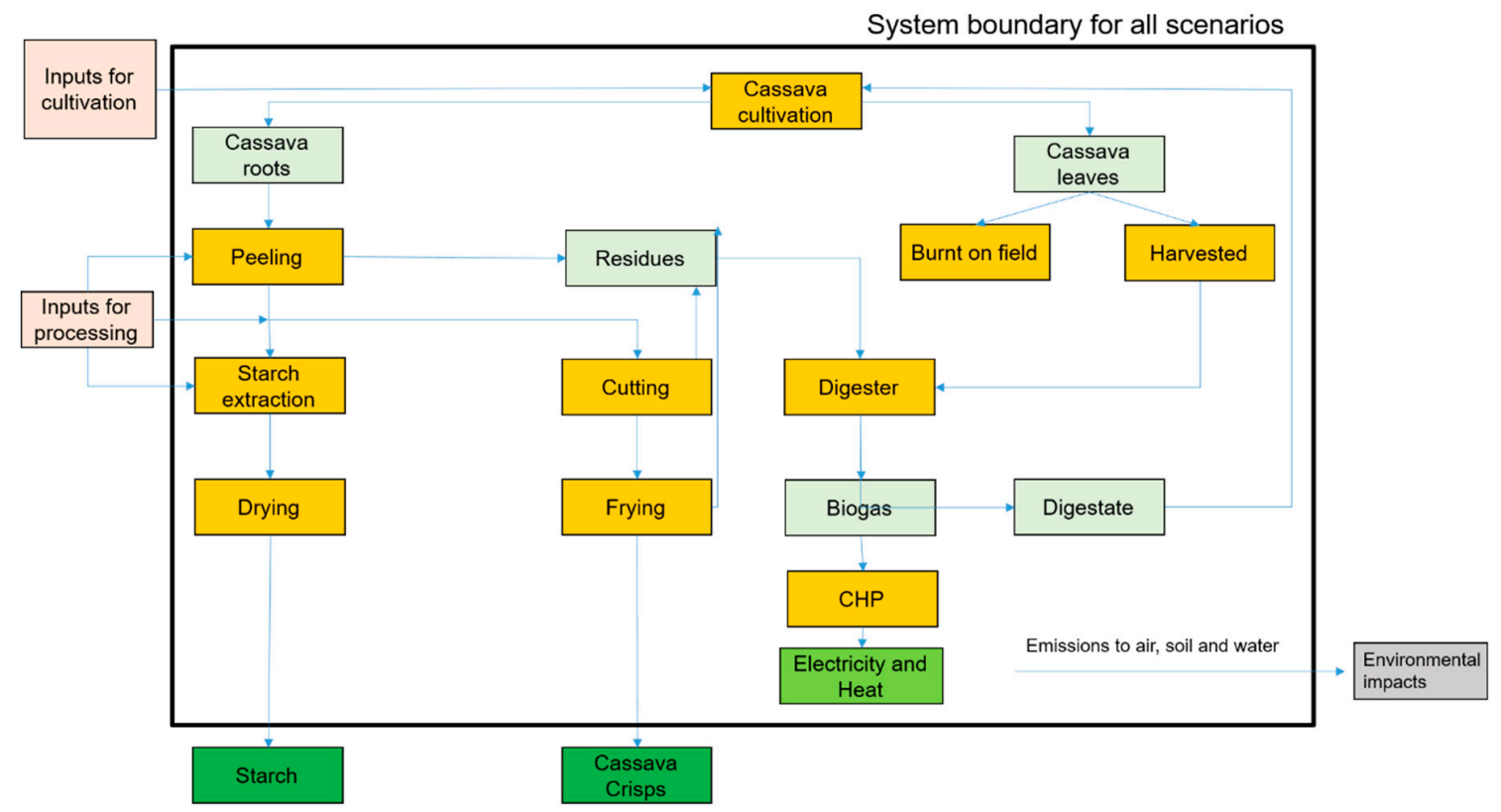

Figure 1. System boundaries of the life cycle assessment (LCA) study (FU: $1 \mathrm{~kg}$ of cassava starch, either in the form of dried native starch or based on the corresponding starch content in cassava crisps).

The modelling principles are based on the international standards ISO 14040 and 14044 [23,24]. "SimaPro 9.0" software (PRé Sustainability, LE Amersfoort, The Netherlands) was used for LCA modelling with "ecoinvent 3.5" database (ecoinvent, Zurich, Switzerland) [25] for background life cycle inventories (LCI) such as infrastructure, the provision of energy carriers, agricultural machinery and mineral fertilizers as well as for the calculation of savings from avoided products. Agricultural primary production, including the calculation of direct field emissions was modelled according to the Swiss Agricultural Life Cycle Assessment method (SALCA) (Agroscope, Zurich, Switzerland) [26] based on the methodological approach described in [27].

\subsubsection{Scenarios}

Four scenarios were differentiated. A basic distinction was made between primary agricultural production and processing. In both cases, there are two sub-scenarios. Primary production is divided into: (i) a traditional scenario where the field work is carried out manually and (ii) a modern scenario where the field work is mechanized. In both cases, at harvest, the leaves of the cassava plants are left and burned in the field. In terms of processing, a distinction has been made between: (i) the industrial scenario where starch is produced, and (ii) an advanced scenario where crisps are produced. In both cases, there is a sub-scenario at which it was assumed that the leaves are harvested and used together with the processing residues as feedstock for biogas production. An overview of the described scenarios can be found in Table 3.

Table 3. Composition of scenarios.

\begin{tabular}{ccccc}
\hline Production Step & Traditional & Modern & Industrial & Advanced \\
\hline Manual field-work & $\mathrm{x}$ & - & - & - \\
Mechanized field-work & - & $\mathrm{x}$ & $\mathrm{x}$ & $\mathrm{x}$ \\
Leaves burnt & $\mathrm{x}$ & $\mathrm{x}$ & - & - \\
Leaves harvested & - & - & $\mathrm{x}$ & $\mathrm{x}$ \\
Starch production & - & - & $\mathrm{x}$ & - \\
Crisp production & - & - & - & $\mathrm{x}$ \\
Biogas & - & - & $\mathrm{x}$ & \\
\hline
\end{tabular}




\subsubsection{LCI Data}

The primary data for cassava cultivation were collected in Malaysia by a questionnaire in the years 2016/2017 and complemented with data from literature. Pesticide application was modelled based on data from [28]. Table 4 shows the emission models used in this study for calculation of direct field emissions.

Table 4. Emission models used (adapted from [27]).

\begin{tabular}{cc}
\hline Emission & Emission Model \\
\hline Ammonia $\left(\mathrm{NH}_{3}\right)$ & EMEP Tier 2 [29] \\
Nitrogen oxides $\left(\mathrm{NO}_{\mathbf{x}}, \mathrm{NO}, \mathrm{NO}_{2}\right)$ & EMEP [29] \\
Nitrous oxide $\left(\mathrm{N}_{2} \mathrm{O}\right)$ & IPCC Tier1 [30] \\
Nitrate $\left(\mathrm{NO}_{3}{ }^{-)}\right.$ & SQCB [31] \\
Phosphorous $\left(\mathrm{P}, \mathrm{PO}_{4}{ }^{3-}\right)$ & SALCA-P [32] \\
Carbon dioxide $\left(\mathrm{CO}_{2}\right)$ & Freiermuth [33] \\
Heavy metals $\left(\mathrm{Cd}, \mathrm{Cr}, \mathrm{Cu}, \mathrm{Hg}_{1} \mathrm{Ni}, \mathrm{Zn}\right)$ & IPCC [30] \\
\hline
\end{tabular}

In more detail, the following formulas were used for calculation of direct emissions (adapted from [27]).

For ammonia $\left(\mathrm{NH}_{3}\right)$ emissions to air, the following equation was used:

$$
\left.\mathrm{NH}_{3}=\frac{17}{14} \cdot \sum_{1}^{m}\left(\left(p \cdot E F_{a m}+(1-p) \cdot E F_{b m}\right)\right) \cdot N_{m i n} \cdot \mathrm{Mm}-1\right),
$$

where $\mathrm{NH}_{3}$ is ammonia emission after mineral fertilizer application $\left(\mathrm{kg} \mathrm{NH}_{3}\right), m$ is fertilizer type $(M$ is number of fertilizer types), $E F_{a m}$ is emission factor on soils with $\mathrm{pH} \leq 7(\mathrm{~kg} \mathrm{NH}-\mathrm{N} / \mathrm{kg} \mathrm{N}), E F_{b m}$ is emission factor on soils with $\mathrm{pH}>7\left(\mathrm{~kg} \mathrm{NH}_{3}-\mathrm{N} / \mathrm{kg} \mathrm{N}\right), p$ is fraction of soils with $\mathrm{pH} \leq 7(\% / 100)$ and $N_{\text {min }}$ is mineral fertiliser application ( $\left.\mathrm{kg} \mathrm{N} / \mathrm{ha}\right)$.

The emissions of various nitrogen oxides $\left(\mathrm{NO}_{\mathrm{x}}, \mathrm{NO}, \mathrm{NO}_{2}\right)$ were calculated based on the remaining $\mathrm{N}$ after $\mathrm{NH}_{3}$ emission. The emission factor for the application of all types of mineral and organic fertilizer is $0.012 \mathrm{~kg} \mathrm{NO}-\mathrm{N}$ per $\mathrm{kg}$ of applied $\mathrm{N}$ based on [29].

For the calculation of nitrate $\left(\mathrm{NO}_{3}\right)$ leaching to ground water, the SQCB-NO model was used as reported in [31]:

$$
\mathrm{NO}_{3}=21.37+\frac{P}{C \cdot L}\left(0.0037 \cdot N_{\text {sup }}+0.0000601 \cdot N_{\text {org }}-0.00362 \cdot N_{u p}\right),
$$

where $\mathrm{NO}_{3}$ is leached $\mathrm{NO}_{3}-\mathrm{N}(\mathrm{kg} \mathrm{N} /($ ha a $)), P$ is precipitation and irrigation $(\mathrm{mm} / \mathrm{year}), c$ is clay content (\%), $L$ is rooting depth $(\mathrm{m}), N_{\text {sup }}$ is nitrogen supply through fertilizer $(\mathrm{kg} \mathrm{N} / \mathrm{ha}), N_{\text {org }}$ is nitrogen in organic matter ( $\mathrm{kg} \mathrm{N} / \mathrm{ha})$ and $N_{u p}$ is nitrogen uptake by crop ( $\left.\mathrm{kg} \mathrm{N} / \mathrm{ha}\right)$.

Nitrous oxide $\left(\mathrm{N}_{2} \mathrm{O}\right)$ from nitrification and denitrification processes are considered by the following equation:

$$
\mathrm{N}_{2} \mathrm{O}=\frac{44}{28} \cdot\left(0.01\left(N_{t o t}+N_{c r}+N_{s o m}+\frac{14}{17} \cdot \mathrm{NH}_{3}+\frac{14}{46} \cdot \mathrm{NO}_{x}\right)+0.0075 \cdot \frac{14}{62} \cdot \mathrm{NO}_{3}\right),
$$

where $\mathrm{N}_{2} \mathrm{O}$ is the emission of $\mathrm{N}_{2} \mathrm{O}\left(\mathrm{kg} \mathrm{N} \mathrm{N}_{2} \mathrm{O} /\right.$ ha a), $N_{\text {tot }}$ is total nitrogen in mineral and organic fertiliser ( $\mathrm{kg} \mathrm{N} / \mathrm{ha}), N_{c r}$ is nitrogen contained in the crop residues $(\mathrm{kg} \mathrm{N} / \mathrm{ha}), N_{\text {som }}$ is nitrogen from the mineralization of soil organic matter $(\mathrm{kg} \mathrm{N} / \mathrm{ha}), \mathrm{NH}_{3}$ is the loss of nitrogen in the form of ammonia $(\mathrm{kg} \mathrm{NH} / \mathrm{ha}), \mathrm{NO}_{\mathrm{x}}$ is losses of nitrogen in the form of nitrogen oxides $\left(\mathrm{kg} \mathrm{NO}_{2} / \mathrm{ha}\right)$ and $\mathrm{NO}_{3}$ is the loss of nitrogen in the form of nitrate $\left(\mathrm{kg} \mathrm{NO}_{3} / \mathrm{ha}\right)$.

For urea application, in addition, $\mathrm{CO}_{2}$ emission were also calculated at $1.57 \mathrm{~kg} \mathrm{CO}_{2}$ per $\mathrm{kg}$ of applied urea-N. 
Regarding phosphorus emissions to water, the following pathways have been differentiated according to [27,32]: (i) leaching of $\mathrm{PO}_{4}$ to ground water, (ii) run-off of $\mathrm{PO}_{4}$ to surface water, and (iii) phosphorus emissions to surface water through soil particles transported by water erosion.

Heavy metal emissions to soil, surface water and ground water were calculated for $\mathrm{Cd}, \mathrm{Cr}, \mathrm{Cu}, \mathrm{Pb}$, $\mathrm{Hg}, \mathrm{Ni}, \mathrm{Zn}$ according to the SALCA-heavy metal method, as described in [33].

Pesticide emissions were modelled based on the assumption that $100 \%$ of the active ingredients applied will end up in the soil. This assumption is in accordance with the current modelling approach of renowned LCI databases like "ecoinvent" and "USDA LCA digital commons" [34].

\subsection{Life Cycle Impact Assessment (LCIA)}

The following impact categories were selected for this study, each of which are related to $1 \mathrm{~kg}$ starch output (FU): cumulated energy demand (CED) in Megajoule (MJ), deforestation (DEF) in $\mathrm{m}^{2}$ forest loss, water stress index (WSI) in $\mathrm{m}^{3}$ consumed water, global warming potential (GWP) in $\mathrm{kg}$ $\mathrm{CO}_{2}$-eq, photochemical ozone formation potential (OFP) in kg NMVOC-equivalents (non-methane volatile organic compounds), acidification potential (AP) in $\mathrm{mol} \mathrm{H}^{+}$, human toxicity potential (HTP) and aquatic ecotoxicity potential (ETP) both in kg 1,4-DB-equivalents (dichlorobenzene). More details regarding the selected impact assessment categories are described by Bystricky et al. [35].

\section{Results and Discussion}

\subsection{Cassava Cultivation}

Impacts from cassava cultivation are expressed per $\mathrm{kg}$ of harvested cassava root and a distinction is made between the following contribution groups: (i) direct field emissions, (ii) mineral fertilizer production, (iii) field work processes, (iv) pesticide production, (v) transport, and (vi) the burning of cassava leaves. Direct field emission means environmental impact from those emissions that are caused by the application of fertilizers and pesticides in the field. Mineral fertilizer production and pesticide production describe the environmental impact of providing the respective inputs of mineral fertilizers and pesticides. Transport includes both the provision and the operation of the means of transport. Burning means the environmental impacts from the combustion of cassava leaves on the field.

Environmental impacts of traditional cassava cultivation are dominated by the production of mineral fertilizers (75-98\%) for input-related LCIA categories (CED, DEF, WSI) and by direct field emissions (40-100\%) for output-related LCIA categories (GWP, OFP, AP, HTP, ETP) (Figure 2). Mineral fertilizer production is governing CED because of the high energy demand of chemotechnical nitrogen and phosphate recovery. Emissions contributing to the GWP of traditional cassava cultivation are mainly $\mathrm{N}_{2} \mathrm{O}$ and $\mathrm{CO}_{2}$ from fertilization with $60 \%$ and $37 \%$, respectively. The burning of the leaves causes environmental impacts mainly in the two impact categories OFP and AP, with contributions of $39 \%$ and $6 \%$, respectively. Most relevant emissions in this context are $\mathrm{N}_{2} \mathrm{O}$ and $\mathrm{SO}_{2}$, which are causing $98 \%$ and $2 \%$ of the total OFP impacts, respectively.

For modern cassava cultivation, Figure 2 shows that the direct field emissions dominate most output-related LCIA categories (GWP, AP, HTP and ETP) system with 39\%, 84\%, 86\% and 100\%, respectively. A high share of direct emissions in total environmental impacts is also reported by Bystricky et al. for potato production [36]. Emissions contributing to the GWP of cassava are mainly $\mathrm{CO}_{2}$ and $\mathrm{N}_{2} \mathrm{O}$ with $60 \%$ and $36 \%$, respectively. Direct field emissions from nitrogen fertilization are the source of $\mathrm{N}_{2} \mathrm{O}$, while exhaust gases from tractors and harvesting machines used in the modern cultivation system are causing more direct $\mathrm{CO}_{2}$ emissions in comparison to traditional production. The burning of leaves contributes with $11 \%$ and $2 \%$ to OFP and AP, respectively. Input-related LCIA categories (CED, DEF) are mainly dominated by field-work processes $(40 \%, 46 \%)$ and transport $(35 \%$, $44 \%)$, while, for WSI, the production of mineral fertilizers (64\%) is the biggest contributor. The great influence of mineral fertilizer production on the WSI is initially surprising. In a more in-depth analysis, it was found that impacts for WSI from mineral fertilizer production are mainly caused by up-stream 
processes for phosphate recovery, namely phosphoric acid and sulfuric acid. Even more surprising is the high influence of transport processes on DEF. Again, an up-stream process is responsible for this; onshore wells that produce the fuels used in the transport processes cause $95 \%$ of these impacts.

In addition to the difference in mechanization, different yields in both systems lead to differences in the results.

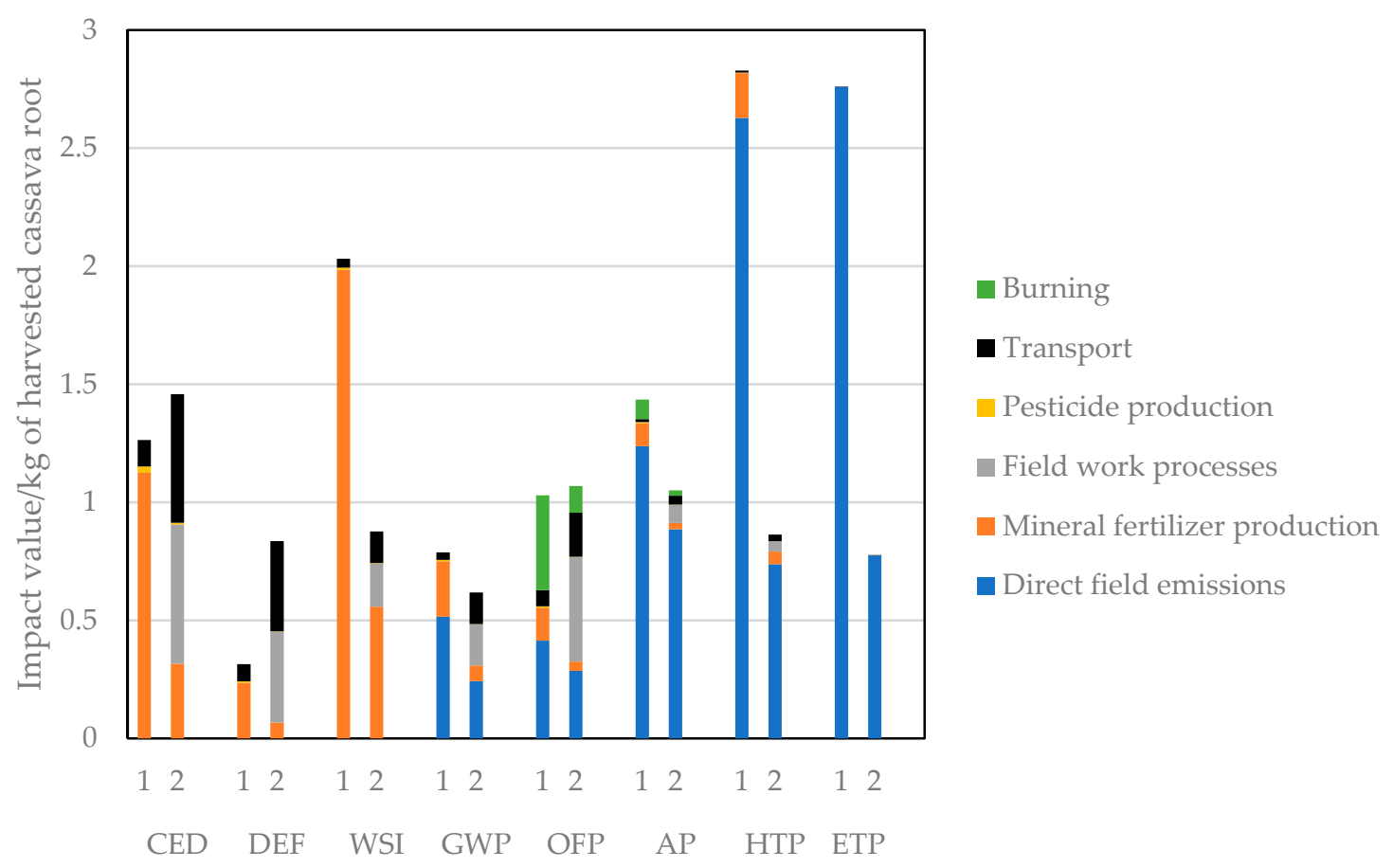

Figure 2. Environmental impacts of traditional (1) and modern (2) cassava cultivation per $\mathrm{kg}$ of harvested cassava root; cumulated energy demand (CED) in MJ, deforestation (DEF) in $4 \times 10^{-3} \mathrm{~m}^{2}$, water stress index (WSI) in $4 \times 10^{-2} \mathrm{~m}^{3}$, global warming potential (GWP) in $4 \times 10^{0} \mathrm{~kg} \mathrm{CO}_{2}$-eq, ozone formation potential (OFP) in $10^{-2} \mathrm{~kg}$ NMVOC-eq, acidification potential (AP) in $2 \times 10^{-1} \mathrm{~mol}$ $\mathrm{H}^{+}$, human toxicity potential (HTP) in $10^{-4} \mathrm{~kg} 1,4$-DB-eq and ecotoxicity potential (ETP) in $10^{-2} \mathrm{~kg}$ 1,4-DB-eq.

\subsection{Cassava Processing and the Utilization of Processing Residues for Biogas Production}

Figure 3 shows the environmental impacts of industrial and advanced cassava processing, including cassava cultivation and taking into consideration the credits from biogas production and utilization. Environmental impacts are expressed per $\mathrm{kg}$ of starch content to allow a comparison of the two main products from both production systems, i.e., cassava starch and cassava crisps. The following contribution groups are differentiated: (i) the processing of peeled cassava roots to starch and crisps, respectively, (ii) the washing and peeling of harvested cassava roots, (iii) cassava cultivation, and (iv) credits from the utilization of processing residues for biogas production and the utilization of the biogas for the generation of electricity and process heat.

The total impacts of CED, DEF and GWP in the industrial scenario are $9.48 \mathrm{MJ} / \mathrm{FU}, 0.0001 \mathrm{~m}^{2} / \mathrm{FU}$ and $1.02 \mathrm{~kg} \mathrm{CO}$-eq./FU, respectively. The results indicate that, in the industrial scenario, the utilization of cassava pulp and leaves for anaerobic digestion and the substitution of electricity and heat from conventional sources lead to environmental advantages in all impact categories The highest relative reductions of environmental impacts by the integration of biogas are achieved for CED, DEF and GWP with $-28 \%,-15 \%$ and $-21 \%$, respectively. 


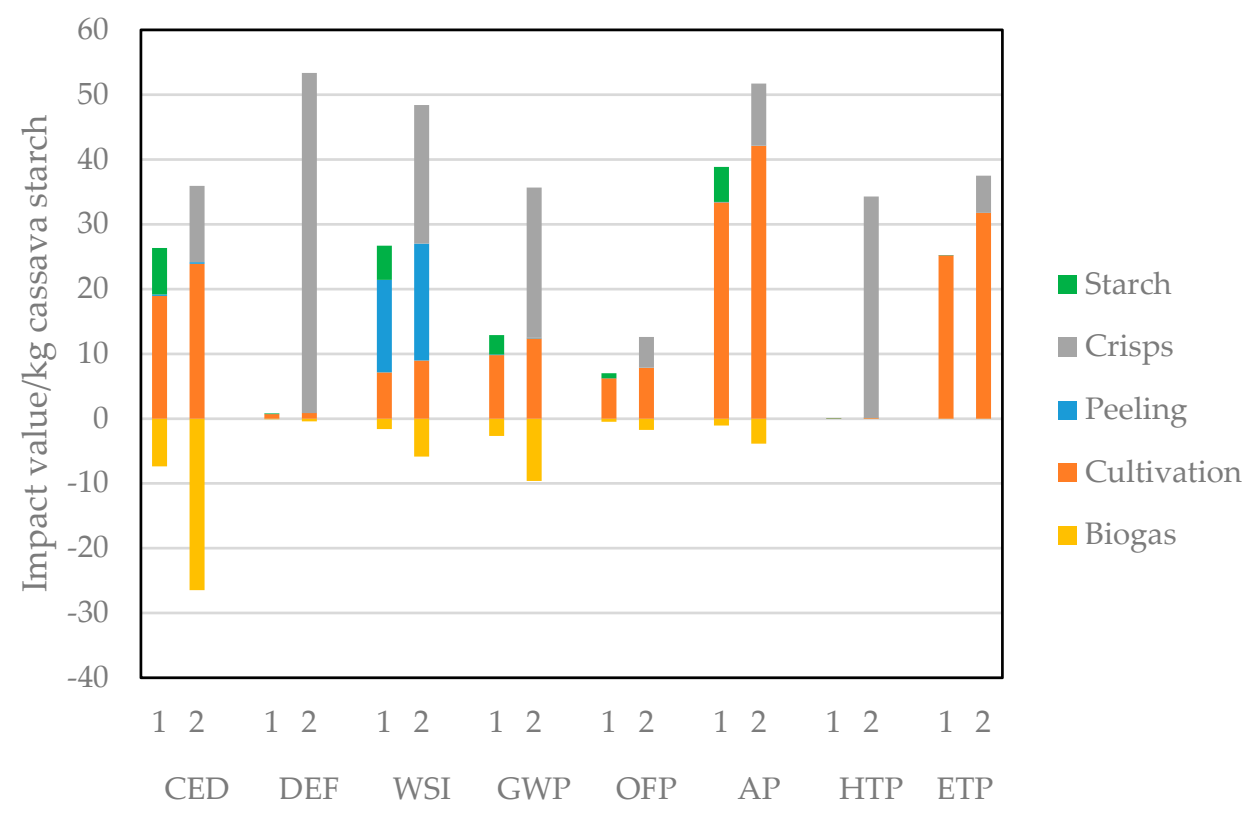

Figure 3. Environmental impacts of industrial (1) and advanced (2) cassava processing per $\mathrm{kg}$ of starch output; cumulated energy demand (CED) in MJ, deforestation (DEF) in $5 \times 10^{-3} \mathrm{~m}^{2}$, water stress index (WSI) in $5 \times 10^{-3} \mathrm{~m}^{3}$, global warming potential (GWP) in $10^{-1} \mathrm{~kg} \mathrm{CO}_{2}$-eq, ozone formation potential (OFP) in $10^{-3} \mathrm{~kg}$ NMVOC-eq, acidification potential (AP) in $10^{-3} \mathrm{~mol} \mathrm{H}^{+}$, human toxicity potential (HTP) in $10^{-2} \mathrm{~kg} 1,4-\mathrm{DB}$-eq, and ecotoxicity potential (ETP) in $5 \times 10^{-2} \mathrm{~kg} 1,4$-DB-eq.

In the advanced scenario, the total impacts of CED, DEF, GWP, OFP and WSI are $4.71 \mathrm{MJ} / \mathrm{FU}$, $0.01 \mathrm{~m}^{2} / \mathrm{FU}, 2.6 \mathrm{~kg} \mathrm{CO}$-eq./FU, $0.01 \mathrm{~kg}$ NMVOC-eq./FU and $0.01 \mathrm{~m}^{3} / \mathrm{FU}$, respectively. The results indicate that the environmental impacts of cassava crisps can be reduced by the utilization of residues for biogas production. CED, GWP, OFP and WSI can be reduced by more than $10 \%$ with $-74 \%,-27 \%$, $-14 \%$ and $-12 \%$, respectively. The credit for the substitution of conventional electricity and heat is the reason for these reductions of environmental impacts. The main contribution to the credit comes from electricity with $77 \%$ and $82 \%$ for CED and GWP, respectively. This is mainly due to the fact, that electricity production from hard coal has a share of $39 \%$ in the Malaysian electricity mix, while only LPG is substituted for heat.

Figure 4 shows that most LCIA categories of the industrial production are dominated by the agricultural cultivation stage (72-100\%). The exception is WSI, for which contributions of cultivation $(27 \%)$, cassava root peeling (54\%) and starch production (20\%) are relevant. These results are different for the advanced production system. Here, CED, OFP, AP and ETP are also mostly driven by cultivation with $66 \%, 62 \%, 81 \%$ and $100 \%$, respectively. On the contrary, for DEF, GWP, and HTP, crisp production has the biggest contribution to overall impacts with $98 \%, 65 \%$ and $94 \%$, respectively. Especially for DEF, this result was unexpected as one would assume the cassava cultivation should be most relevant here. For all three impact categories, the high contribution to this impact is caused by a background process used in the processing, namely palm oil for frying. For DEF and GWP, deforestation and the related GHG emissions are responsible for this. In the case of HTP, it is pesticide application in palm oil production. Consequently, here, a processed agricultural product from the upstream chain has a significant influence on the overall impacts. This is linked to the fact that it was assumed that non-certified palm oil is used. When comparing the absolute values, it is noticeable that the advanced scenario leads to higher overall environmental impacts than the industrial scenario. This is mainly due to the high energy demand and the use of palm oil for deep-frying the crisps, which are also the main drivers of environmental impacts in the advanced scenario. The latter finding is in line with the environmental hotspots of French fries described by Mouron et al. [17] as well as the results for fried insects and soy meal-based meat substitutes, as reported by Smetana et al. [37]. 


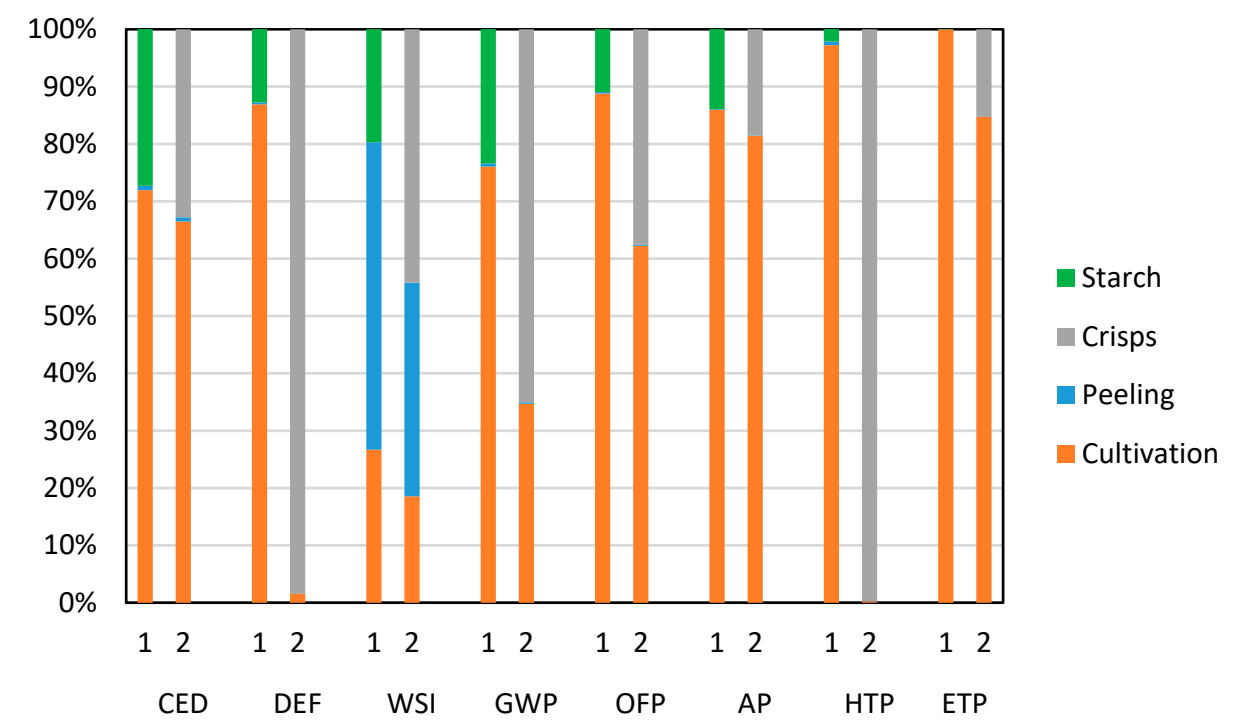

Figure 4. Relative contribution to environmental impacts of the various processing steps in industrial (1) and advanced (2) cassava processing; cumulated energy demand (CED), deforestation (DEF), water stress index (WSI), global warming potential (GWP), ozone formation potential (OFP), acidification potential (AP), human toxicity potential (HTP) and ecotoxicity potential (ETP).

With regard to the entire process chain, the results show that primary agricultural production has a significant influence on the overall environmental impact of cassava starch in most impact categories. This is in line with the findings of other studies that only considered the GWP [11]. The total impacts of GWP found in this study are higher but in the same order of magnitude compared to another study that focused on the carbon footprint of starch production from cassava, while savings due to biogas production are similar [12].

\section{Conclusions}

This study delivered full life cycle assessment (LCA) results from the production of cassava starch and cassava crisps, including the primary production of cassava roots. The results show that primary agricultural production has a significant influence on the overall environmental impact of cassava starch in most impact categories. Furthermore, the analysis showed that differences in the environmental impacts per $\mathrm{kg}$ of cassava root of traditional and modern cassava production are mainly due to different yields in both systems as well as the different levels of mechanization. The results indicate that the environmental impacts of cassava-based products can be reduced considerably with the utilization of processing residues for anaerobic digestion if the resulting biogas is used for the production of electricity and process heat. The relative contributions of these environmental advantages differ between the two production systems analyzed and vary between impact categories. In contrast, the global warming potential (GWP) of cassava crisp production is dominated by processing. This results in different hotspots for these two production systems and thus in different approaches to reduce environmental impacts. In the case of cassava starch production, it is advisable to optimize agricultural cultivation processes. In the case of cassava crisp production, it is mainly the palm oil for deep-frying that significantly contributes to environmental impacts that possibly could be reduced by purchasing certified palm oil. This would have to be verified by further research.

Author Contributions: Conceptualization, J.L., S.A. and S.L.; methodology, J.L.; software, J.L.; validation, J.L. and S.A.; formal analysis, J.L.; investigation, S.A.; resources, S.A.; data curation, J.L; writing-original draft preparation, J.L.; writing - review and editing, S.A., S.L. and J.M.; visualization, J.L., supervision, J.M and S.L.; project administration, S.L. and J.M.; funding acquisition, S.L. and J.M. All authors have read and agreed to the published version of the manuscript. 
Funding: This research was funded by German Federal Ministry of Education and Research (BMBF) under Project No. 031B0217 "CassavaUpgrade".

Conflicts of Interest: The authors declare no conflict of interest.

\section{References}

1. FAO. FAOSTAT Database; Food and Agriculture Organization of the United Nations: Rome, Italy, 2019.

2. Latif, S.; Müller, J. Cassava-How to explore the "all-sufficient". Rural 21 2014, 3, 2.

3. Latif, S.; Müller, J. Potential of cassava leaves in human nutrition: A review. Trends Food Sci. Technol. 2015, 44, 147-158. [CrossRef]

4. Vetter, J. Plant cyanogenic glycosides. Toxicon 2000, 38, 11-36. [CrossRef]

5. Corona, A.; Ambye-Jensen, M.; Vega, G.C.; Hauschild, M.Z.; Birkved, M. Techno-environmental assessment of the green biorefinery concept: Combining process simulation and life cycle assessment at an early design stage. Sci. Total Environ. 2018, 635, 100-111. [CrossRef] [PubMed]

6. Abdeshahian, P.; Lim, J.S.; Ho, W.S.; Hashim, H.; Lee, C.T. Potential of biogas production from farm animal waste in Malaysia. Renew. Sustain. Energy Rev. 2016, 60, 714-723. [CrossRef]

7. Abdullah, W.S.W.; Osman, M.; Kadir MZ, A.A.; Verayiah, R. The Potential and Status of Renewable Energy Development in Malaysia. Energies 2019, 12, 2437. [CrossRef]

8. Lian, T.S.; Idris, K. Present situation and future potential of cassava in Malaysia. In Proceedings of the Sixth Regional Workshop, Ho Chi Minh City, Vietnam, 21-25 February 2000.

9. Tran, T.; Da, G.; Alonso, M.; Moreno-Santander, Adolfo, G.; Vélez-Hernández; Giraldo-Toro, A.; Piyachomkwan, K.; Sriroth, K.; Dufour, D. A comparison of energy use, water use and carbon footprint of cassava starch production in Thailand, Vietnam and Colombia. Resour. Conserv. Recycl. 2015, 100, 31-40. [CrossRef]

10. Torquati, B.; Venanzi, S.; Ciani, A.; Diotallevi, F.; Tamburi, V.; Asdrubali, F. Environmental sustainability and economic benefits of dairy farm biogas energy production: A case study in Umbria. Sustainability 2014, 6, 6696-6713. [CrossRef]

11. Usubharatana, P.; Phungrassami, H. Carbon footprint of cassava starch production in North-Eastern Thailand. Proced. CIRP 2015, 29, 462-467. [CrossRef]

12. Hansupalak, N.; Piromkraipak, P.; Tamthirat, P.; Manitsorasak, A.; Sriroth, K.; Tran, T. Biogas reduces the carbon footprint of cassava starch: A comparative assessment with fuel oil. J. Clean. Prod. 2016, 134, 539-546. [CrossRef]

13. Olaniran, J.; Jekayinfa, S.; Agbarha, H. Life cycle assessment of cassava flour production: A case study in Southwest Nigeria. J. Eng. Technol. Res. 2017, 9, 6-13. [CrossRef]

14. United Nations (UN). Sustainable Development Goals; Sustainable Development Goals: New York, NY, USA,2015.

15. Sala, S.; Castellani, V. The consumer footprint: Monitoring sustainable development goal 12 with process-based life cycle assessment. J. Clean. Prod. 2019, 240, 118050. [CrossRef] [PubMed]

16. Chavalparit, O.; Ongwandee, M. Clean technology for the tapioca starch industry in Thailand. J. Clean. Prod. 2009, 17, 105-110. [CrossRef]

17. Mouron, P.; Willersinn, C.; Möbius, S.; Lansche, J. Environmental profile of the swiss supply chain for French fries: Effects of food loss reduction, loss treatments and process modifications. Sustainability 2016, 8, 1214. [CrossRef]

18. Vitrac, O.; Dominique, D.; Trystram, G.; Raoult-Wack, A.-L. Deep-fat frying of cassava: Influence of raw material properties on chip quality. J. Sci. Food Agric. 2001, 81, 227-236. [CrossRef]

19. Phairuang, W.; Hata, M.; Furuuchi, M. Influence of agricultural activities, forest fires and agro-industries on air quality in Thailand. J. Environ. Sci. 2017, 52, 85-97. [CrossRef] [PubMed]

20. Standard, V. VDI 4630 Fermentation of Organic Materials. Characterization of the Substrate, Sampling, Collection of Material Data, Fermentation Tests; Verlag des Vereins Deutscher Ingenieure: Düsseldorf, Germany, 2006; p. 92.

21. Grünwasser, S. Determination of the influence of hydrocyanic acid glycosides on the biogas yield potential of cassava leaves (in German). In Institut für Agrartechnik; Universität Hohenheim: Stuttgart, Germany, 2017.

22. Awiszus, S. Methane Production Potential of Cassava Bagasse; Universität Hohenheim: Stuttgart, Germany, 2019. 
23. ISO. ISO 14044_Environmental Management_Life Cycle Assessment_Requirements and Guidelines; ISO: Geneva, Switzerland, 2006.

24. ISO. ISO 14040_Environmental Management_Life Cycle Assessment_Principles and Framework; ISO: Geneva, Switzerland, 2006.

25. Ecoinvent Centre. Ecoinvent Data-The Life Cycle Inventory Data V3.3; Swiss Centre for Life Cycle Inventories: Dübendorf, Switzerland, 2016.

26. Gaillard, G.; Nemecek, T. Swiss Agricultural Life Cycle Assessment (SALCA): An integrated environmental assessment concept for agriculture. In Proceedings of the Integrated Assessment of Agriculture and Sustainable Development, Setting the Agenda for Science and Policy, Egmond aan Zee, The Netherlands, 10-12 March 2009; AgSAP Office, Wageningen University: Egmond aan Zee, The Netherlands, 2009.

27. Nemecek, T.; Bengoa, X.; Lansche, J.; Mouron, P.; Riedener, E.; Rossi, V.; Humbert, S. Methodological Guidelines for the Life Cycle Inventory of Agricultural Products. Version 3.0, July 2015; World Food LCA Database (WFLDB); Quantis and Agroscope: Lausanne, Switzerland, 2015; p. 84.

28. Hanif, M.; Mahlia, T.M.I.; Aditiya, H.B.; Bakar, M.S.A. Energy and environmental assessments of bioethanol production from Sri Kanji 1 cassava in Malaysia. Biofuel Res. J. 2017, 4, 537-544. [CrossRef]

29. EEA. EMEP/EEA air pollutant emission inventory guidebook 2013-Technical guidance to prepare national emission inventories. In EEA Technical Report No 12/2013; European Environment Agency: Luxembourg, 2013.

30. IPCC. 2006 IPCC Guidelines for National Greenhouse Gas Inventories. Volume 4: Agriculture, Forestry and Other Land Use; Eggleston, S., Buendia, L., Miwa, K., Ngara, T., Tanabe, K., Eds.; IGES: Kanagawa, Japan, 2006.

31. Faist Emmenegger, M.; Reinhard, J.; Zah, R. Sustainability Quick Check for Biofuels_Intermediate Background Report; EMPA: Dübendorf, Switzerland, 2009; p. 129.

32. Prasuhn, V. Erfassung der $\mathrm{PO}_{4}$-Austräge für die Ökobilanzierung-SALCA-Phosphor; Agroscope FAL Reckenholz: Zürich, Switzerland, 2006; p. 22.

33. Freiermuth, R. Modell zur Berechnung der Schwermetallflüsse in der Landwirtschaftlichen Ökobilanz; Agroscope FAL Reckenholz: Zürich, Switzerland, 2006; p. 42.

34. Rosenbaum, R.K.; Anton, A.; Bengoa, X.; Bjørn, A.; Brain, R.; Bulle, C.; Cosme, N.; Dijkman, T.J.; Fantke, P.; Felix, M.; et al. The Glasgow consensus on the delineation between pesticide emission inventory and impact assessment for LCA. Int. J. Life Cycle Assess. 2015, 20, 765-776. [CrossRef]

35. Bystricky, M.; Nemecek, T. SALCA-Emissionsmodelle: Anwendung in Österreich; Abschlusstagung des Projektes FarmLife; Höhere Bundeslehr-und Forschungsanstalt Raumberg-Gumpenstein: Irdning, Austria, 2015; pp. 23-32.

36. Bystricky, M.; Alig Ceesay, M.; Nemecek, T.; Gaillard, G. Ökobilanz ausgewählter Schweizer Landwirtschaftsprodukte im Vergleich zum Import. Agroscope Sci. 2014, 2, 1-177.

37. Smetana, S.; Mathys, A.; Knoch, A.; Heinz, V. Meat alternatives: Life cycle assessment of most known meat substitutes. Int. J. Life Cycle Assess 2015, 20, 1254-1267. [CrossRef] 